\title{
Loss of insulin-induced inhibition of glucagon gene transcription in hamster pancreatic islet alpha cells by long-term insulin exposure
}

\author{
M. González • U. Böer • C. Dickel • T. Quentin • \\ I. Cierny $\cdot$ E. Oetjen $\cdot$ W. Knepel
}

Received: 20 March 2008 / Accepted: 29 July 2008 / Published online: 2 September 2008

(C) The Author(s) 2008. This article is published with open access at Springerlink.com

\begin{abstract}
Aims/hypothesis Diabetes mellitus type 2 is characterised by hyperglucagonaemia, resulting in hepatic glucose production and hyperglycaemia. Considering that insulin inhibits glucagon secretion and gene transcription, hyperglucagonaemia in the face of hyperinsulinaemia in diabetes mellitus type 2 suggests that there is insulin resistance also at the glucagon-producing pancreatic islet alpha cells. However, the molecular mechanism of alpha cell insulin resistance is unknown. Therefore, the effect of molecules implicated in conferring insulin resistance in some other tissues was investigated on insulin-induced inhibition of glucagon gene transcription in alpha cells.

Methods Reporter gene assays and biochemical techniques were used in the glucagon-producing hamster pancreatic islet alpha cell line InR1-G9.
\end{abstract}

Electronic supplementary material The online version of this article (doi:10.1007/s00125-008-1134-5) contains supplementary material, which is available to authorised users.

M. González · U. Böer · C. Dickel · I. Cierny · E. Oetjen $(\bowtie) \cdot$

W. Knepel

Molecular Pharmacology, University of Göttingen,

Robert-Koch Str. 40,

37099 Göttingen, Germany

e-mail: eoetjen@med.uni-goettingen.de

T. Quentin

Pediatric Cardiology and Intensive Care Medicine,

University of Göttingen,

Göttingen, Germany

Present address:

M. González

Department of Physiology, McGill University,

McIntyre Medical Sciences Building,

Montreal, QC, Canada, H3G 1Y6
Results From among 16 agents tested, chronic insulin treatment was found to abolish insulin-induced inhibition of glucagon gene transcription. Overproduction of constitutively active protein kinase $\mathrm{B}$ (PKB) still inhibited glucagon gene transcription after chronic insulin treatment; together with a markedly reduced insulin-induced phosphorylation and, thus, activation of $\mathrm{PKB}$, this indicates that targets upstream of PKB within the insulin signalling pathway are affected. Indeed, chronic insulin treatment markedly reduced IRS-1 phosphorylation, insulin receptor (IR) autophosphorylation and IR content. Cycloheximide and in vivo labelling experiments attributed IR downregulation to enhanced degradation.

Conclusions/interpretation These results show that an extended exposure of alpha cells to insulin induces IR downregulation and loss of insulin-induced inhibition of glucagon gene transcription. They suggest that hyperinsulinaemia, through IR downregulation, may confer insulin resistance to pancreatic islet alpha cells in diabetes mellitus type 2 .

Keywords Alpha cells · Downregulation · Glucagon · Glucagon gene transcription · Insulin · Insulin receptor . Insulin receptor substrate-1 $\cdot$ Protein kinase $B$

$\begin{array}{ll}\text { Abbreviations } \\ \text { CCL5 } & \text { chemokine (C-C motif) ligand 5 } \\ \text { GAPDH } & \text { glyceraldehyde-3-phosphate dehydrogenase } \\ \text { GFP } & \text { green fluorescent protein } \\ \text { IR } & \text { insulin receptor } \\ \text { PI3K } & \text { phosphatidylinositol 3-kinase } \\ \text { PKB } & \text { protein kinase B } \\ \text { PMSF } & \text { phenylmethylsulfonylfluoride } \\ \text { TNF- } \alpha & \text { tumour necrosis factor- } \alpha \\ \text { TRB3 } & \text { mammalian homologue of Drosophila tribbles } 3\end{array}$




\section{Introduction}

Diabetes mellitus type 2 is associated with insulin resistance of peripheral organs such as skeletal muscle, adipose tissue and the liver [1]. Although the genetic bases and the cellular events that underlie insulin resistance are poorly understood, a great variety of factors have been shown to be involved in the development of this condition in these tissues. Among those factors are pro-inflammatory cytokines, NEFA, hyperinsulinaemia, reactive oxygen species and the mammalian homologue of Drosophila tribbles 3 (TRB3), as well as drugs such as glucocorticoids and the immunosuppressants ciclosporin $\mathrm{A}$ and tacrolimus [1-3]. These factors can promote insulin resistance through several mechanisms. Pro-inflammatory cytokines such as tumour necrosis factor- $\alpha$ (TNF- $\alpha$ ) and IL-6, for example, act through classic receptor-mediated processes to stimulate c-Jun N-terminal kinase 1-mediated serine phosphorylation of IRS-1, I $\kappa$ B kinase-mediated nuclear factor- $\kappa$ B activation, and induction of suppressor of cytokine signalling 3 [1].

Furthermore, diabetes mellitus type 2 is associated with hyperglucagonaemia [4-11]. The peptide hormone glucagon is synthesised in the islets of Langerhans within the pancreas. Islets synthesise different hormones in distinct cell types. Pancreatic islet alpha cells synthesise and secrete glucagon, which in combination with insulin, synthesised by pancreatic beta cells, regulates blood glucose concentrations. Insulin increases peripheral glucose uptake and opposes hepatic glucose production, while glucagon balances the effect of insulin by increasing hepatic glucose production and opposing hepatic glucose storage [9-11]. Glucagon-producing alpha cells are mainly located in the peripheral regions of the islets of Langerhans surrounding the insulin-producing beta cells. Therefore, they are exposed to high concentrations of insulin [9-11]. Acting directly on alpha cells, insulin inhibits glucagon secretion and gene transcription $[12,13]$. Previous studies have shown that insulin inhibits glucagon gene transcription through the activation of phosphatidylinositol 3-kinase $(\mathrm{PI} 3 \mathrm{~K})$ and protein kinase $\mathrm{B}(\mathrm{PKB})$, leading to inhibition of the activity of the transcription factor Pax6, which is essential for the alpha cell-specific activation of the glucagon gene $[12,13]$. The paracrine inhibition of glucagon gene transcription by insulin is an important mechanism in blood glucose control. Consequently, in diabetic patients the relative hyperglucagonaemia contributes to hyperglycaemia in these patients [4-11].

The elevated glucagon levels in the face of hyperinsulinaemia in diabetes mellitus type 2 suggest that there is insulin resistance also of pancreatic islet alpha cells [4-11]. However, what confers insulin resistance to pancreatic islet alpha cells is unknown. Therefore, in the present study, the effect of messenger molecules that have been implicated in conferring insulin resistance to some other tissues on the inhibition by insulin of glucagon gene transcription in pancreatic islet alpha cells was investigated.

\section{Methods}

Materials RPMI 1640 cell culture medium, fetal bovine serum, penicillin/streptomycin solution and trypsin/EDTA were from GIBCO BRL (Karlsruhe, Germany). Bromophenol blue, CellLytic $\mathrm{M}$ cell lysis reagent, cycloheximide, chloroquine, lactacystin, sodium deoxycholate, sodium fluoride, sodium orthovanadate, okadaic acid, porcine insulin, Protein G agarose beads and Triton X-100 were from Sigma-Aldrich (Steinheim, Germany). BSA, glycerol, leupeptin, pepstatin, phenylmethylsulfonylfluoride (PMSF), SDS and TRIS were from Applichem (Darmstadt, Germany). The antibodies for PKB, phospho-Ser473-PKB, insulin receptor (IR)- $\beta$, phospho-Tyr1150/1151-IR and IRS-1 were from Cell Signaling (Danvers, MA, USA). The IR antibody (Ab-3/29B4) for labelling experiments was from Calbiochem (Darmstadt, Germany). The antibody for phospho-Tyr612-IRS-1 was from Biosource (Camarillo, CA, USA). The glyceraldehyde-3-phosphate dehydrogenase (GAPDH) antibody was from Santa Cruz Biotechnology (Santa Cruz, CA, USA). The $\beta$-catenin antibody was from BD Biosciences (Erembodegem, Belgium). The monoclonal antibody against $\beta$-arrestin 1 and 2 was from Bünemann et al. [14]. [ $\left.{ }^{35} \mathrm{~S}\right]$ Methionine (37 TBq/mmol) was from Amersham (Munich, Germany).

Plasmid constructs The plasmid -350GluLuc [12] has been previously described. The plasmid pGFPtpz-cmv[R] (GFP, green fluorescent protein) was from Canberra-Packard (Dreieich, Germany). The expression vectors encoding myr-PKB (pCMV4-PKB ${ }_{\text {myr }}$ ) and myr-PKB-K179M (pCMV4-PKB myr $-\mathrm{K} 179 \mathrm{M}$ ) have been previously described [13]. The expression vector encoding TRB3 (pDNA3-FTTRB-3) was generously provided by S. Herzig, Heidelberg, Germany.

Cell culture and transfection of DNA The glucagonproducing hamster pancreatic islet cell line InR1-G9 [12, 15] was grown in RPMI 1640 medium supplemented with $10 \%$ (vol./vol.) fetal bovine serum, $100 \mathrm{U} / \mathrm{ml}$ penicillin and $100 \mu \mathrm{g} / \mathrm{ml}$ streptomycin. Cells were trypsinised and transfected in suspension by the diethylaminoethyl-dextran method [16] with $2 \mu \mathrm{g}$ of reporter plasmid and the indicated expression vector per $6 \mathrm{~cm}$ dish. In all experiments, $0.5 \mu \mathrm{g}$ of cytomegalovirus-GFP plasmid (pGFPtpz-cmv[R]) per $6 \mathrm{~cm}$ dish was cotransfected to check for transfection efficiency. Twenty-four hours after transfection, the cells were washed once with PBS and the medium was replaced 
by a serum-free medium containing $0.5 \%$ (wt/vol.) BSA supplemented with antibiotics. When indicated, cells were treated with increasing insulin concentrations $23 \mathrm{~h}$ before harvest. Cells extracts were prepared $48 \mathrm{~h}$ after transfection [16]. Luciferase activity was measured as described previously [16], and GFP was measured in cell extracts using the FluoroCount microplate fluorometer (Packard).

Immunoblots For PKB analysis, cells were lysed in preheated $1 \times$ Laemmli buffer $(0.25 \mathrm{mg} / \mathrm{ml}$ bromophenol blue, $10 \%$ (vol./vol.) glycerol, $2 \%$ (wt/vol.) SDS, $62.5 \mathrm{mmol} /$ 1 TRIS pH 6.8 and $2.5 \%$ (vol./vol.) $\beta$-mercaptoethanol), homogenised five times with a syringe (27 G 3/4 inch needle), and boiled for $5 \mathrm{~min}$ before $10 \%$ (wt/vol.) SDSPAGE was performed. Cell lysates for IR and IRS-1 analysis were prepared in ice-cold CellLytic M Cell Lysis Reagent (Sigma-Aldrich) supplemented with the following inhibitors: $1 \mu \mathrm{g} / \mathrm{ml}$ leupeptin, $50 \mathrm{mmol} / 1$ sodium fluoride, $2 \mathrm{mmol} / \mathrm{l}$ sodium orthovanadate, $1 \mu \mathrm{g} / \mathrm{ml}$ pepstatin, $1 \mathrm{mmol} / \mathrm{l} \mathrm{PMSF}$ and $400 \mathrm{nmol} / \mathrm{l}$ okadaic acid. Cells were kept on ice for $5 \mathrm{~min}$, followed by mechanical detachment by means of a scraper. Cells were centrifuged for $15 \mathrm{~min}$ at $12,000 \times \mathrm{g}$. Aliquots of the cell lysates were boiled for $5 \mathrm{~min}$ after addition of $4 \times$ Laemmli buffer. SDS-PAGE analysis of IR and IRS- 1 was performed by using 7.5 and $6 \%$ (wt/vol.) polyacrylamide gels, respectively. Detection of PKB, phospho-Ser473-PKB, IR, phospho-Tyr1150/1151-IR and IRS-1 was performed with specific antibodies (Cell Signaling). Detection of phospho-Tyr612-IRS-1 was performed with an antibody from Biosource. Detection of $\beta$-arrestin 1 and 2 was performed using a monoclonal antibody prepared by Bünemman et al. [14]. All transference procedures were performed by semi-wet transfer with a three-buffer system (buffer 1: 20\% [vol./vol.] methanol, $300 \mathrm{mmol} / \mathrm{l}$ TRIS, pH 11.3; buffer 2: $20 \%$ [vol./vol.] methanol, $25 \mathrm{mmol} / \mathrm{l}$ TRIS, pH 10.5; buffer 3: $20 \%$ [vol./vol.] methanol, $25 \mathrm{mmol} / \mathrm{l}$ TRIS, $\mathrm{pH} 9.0$ ), except for the IRS-1 transference, which required wet transfer with only one buffer ( $20 \%$ [vol./vol.] methanol, $10 \%$ [vol./vol.] $10 \times$ TRIS-glycine buffer $[1.9 \mathrm{~mol} / \mathrm{l}$ glycine, $250 \mathrm{mmol} / 1 \mathrm{TRIS}]$ ). For IR experiments, equal loading was monitored by GAPDH immunoblotting. After incubation with the appropriate primary antibody and horseradish peroxidase-coupled secondary antibody (Amersham Biosciences, Freiburg, Germany), the signal was visualised by enhanced chemiluminescence (Amersham Biosciences). Cytosolic and membrane fractions from InR1-G9 cells for $\beta$-arrestin immunoblotting were prepared as described [17].

Biosynthetic labelling with ${ }^{35}$ SJmethionine Labelling of the IR of InR1-G9 cells with $\left[{ }^{35} \mathrm{~S}\right]$ methionine was performed as previously described [18]. InR1-G9 cells were grown in
RPMI 1640 medium containing 10\% (vol./vol.) fetal bovine serum, 100 units $/ \mathrm{ml}$ penicillin and $100 \mu \mathrm{g} / \mathrm{ml}$ streptomycin [16]. Cells were treated with insulin $(100 \mathrm{nmol} / \mathrm{l}) 2 \mathrm{~h}$ after plating. Twenty-two hours later, cells were washed twice with PBS and were starved for $1 \mathrm{~h}$ in methionine-free medium supplemented with $5 \%$ (vol./vol.) fetal bovine serum and insulin $(100 \mathrm{nmol} / \mathrm{l})$, followed by incubation with $\left[{ }^{35} \mathrm{~S}\right]$ methionine $(1.85 \mathrm{MBq} / \mathrm{ml})$ at $37^{\circ} \mathrm{C}$ for $2 \mathrm{~h}$. Cells were washed twice with cold PBS and $200 \mu \mathrm{l}$ of lysis buffer ( $50 \mathrm{mmol} / 1$ HEPES pH 7.5 containing $150 \mathrm{mmol} / \mathrm{l} \mathrm{NaCl}, 1 \%$ [vol./vol.] Triton X-100, 5 mmol/l EDTA, 5 mmol/l EGTA, $20 \mathrm{mmol} / 1$ sodium pyrophosphate, $1 \mathrm{mmol} / 1$ sodium orthovanadate, $20 \mathrm{mmol} / 1$ sodium fluoride and $1 \mathrm{mmol} / \mathrm{l} \mathrm{PMSF}$ ) was added to the cells. After $5 \mathrm{~min}$, cells were scraped and were homogenised five times with a syringe ( $27 \mathrm{G} 3 / 4$ inch needle). Cell lysates were centrifuged for $15 \mathrm{~min}$ at $18,000 \mathrm{~g}$ $\left(4^{\circ} \mathrm{C}\right)$, and the supernatant fraction was transferred to a new $2 \mathrm{ml}$ tube. Immunoprecipitation was performed by mixing $200 \mu \mathrm{l}$ of cell lysate with $1 \mu \mathrm{g}$ of IR- $\beta$ antibody (Ab3/29B4; Calbiochem). This cell lysate-antibody mix was incubated with gentle rocking overnight at $4^{\circ} \mathrm{C}$. Protein $\mathrm{G}$ agarose beads ( $25 \mu \mathrm{l}$ of a $50 \%$ [vol./vol.] bead slurry) were added to the lysate-antibody mix and were incubated with gentle rocking for $2 \mathrm{~h}$ at $4^{\circ} \mathrm{C}$. The complex was centrifuged for $15 \mathrm{~min}$ at $210 \mathrm{~g}\left(4^{\circ} \mathrm{C}\right)$ and the supernatant fraction was discarded. The beads were washed five times with cell lysis buffer and the pellet was resuspended with $20 \mu$ lof $4 \times$ Laemmli buffer, vortexed and centrifuged for $1 \mathrm{~min}$. The samples were boiled for $5 \mathrm{~min}$ before loading on to a $7.5 \%$ (wt/vol.) SDS gel. Immunoprecipitation results were analysed using a Fuji phosphorimaging device (Raytest-Fuji, Straubenhardt, Germany).

Isolation of islets, RNA isolation, RT-PCR and $m R N A$ quantification Mouse islets (strain NMRI from the Centre of animal experimental facility at the University Göttingen, Germany) were isolated. All animal studies were conducted according to the National Institutes of Health's guidelines for care and use of experimental animals and were approved by the Committee on Animal Care and Use of the local institution and state. Isolation of islets and their culture was performed as described previously [3]. Islets were cultured in RPMI 1640 supplemented with 10\% (vol./vol.) fetal bovine serum, $100 \mathrm{U} / \mathrm{ml}$ penicillin, $100 \mu \mathrm{g} / \mathrm{ml}$ streptomycin, and $5 \mathrm{mmol} / \mathrm{l}$ glucose. After 1 and $23 \mathrm{~h}$, respectively, preincubation islets were treated with $100 \mathrm{nmol} / 1$ insulin for 23 or $46 \mathrm{~h}$ or left untreated. RNA isolation, RT-PCR and mRNA quantification were performed as described previously [19] using the same primers.

Statistical analysis All results are expressed as means \pm SEM. Statistical significance was calculated with ANOVA followed by the indicated tests using the software Statistica 
(StatSoft, Hamburg, Germany). A value of $p<0.05$ was considered significant.

\section{Results}

Effect of factors that have been shown to confer insulin resistance to some other tissues, on insulin-induced inhibition of glucagon gene transcription in InR1-G9 cells A reporter gene containing $350 \mathrm{bp}$ of the $5^{\prime}$-flanking region of the rat glucagon gene (construct -350 GluLuc [12]) was transiently transfected into glucagon-producing InR1-G9 cells. Treatment of InR1-G9 cells with insulin inhibited glucagon gene transcription in a dose-dependent fashion (Fig. 1a), as previously shown [12, 13]. The maximal inhibition by insulin was by about $60 \%$ with an $\mathrm{IC}_{50}$ value of $0.37 \mathrm{nmol} / 1$ (Fig. 1a). A great variety of factors have been shown before to be involved in the development of insulin resistance in skeletal muscle, adipose tissue or the liver, including pro-inflammatory cytokines, NEFA, hyperinsulinaemia, reactive oxygen species and the mammalian homologue of TRB3, as well as drugs such as glucocorticoids and the immunosuppressants ciclosporin $\mathrm{A}$ and tacrolimus [1-3, and references therein]. The effect of these factors on the insulin-induced inhibition of glucagon gene transcription was investigated in the InR1-G9 pancreatic islet alpha cell line (Tables 1 and 2).

From the 16 treatments tested, 14 did not interfere with the insulin-induced inhibition of glucagon gene transcription (Table 2). Some of these, however, changed basal glucagon gene transcription (Table 1). As has been shown before, 8-Br-cAMP stimulated [20] and the immunosuppressants slightly inhibited glucagon gene transcription by themselves [3, 16] (Table 1). TNF- $\alpha$, NEFA and hydrogen peroxide inhibited, while TRB3 stimulated basal glucagon gene transcription (Table 1), which has not been reported before.

Two treatments (IL-1 $\beta$ and chronic insulin) were found to interfere with the insulin-induced inhibition of glucagon gene transcription (Table 2). IL-1 $\beta$ reduced the inhibition by insulin by about $70 \%$ (Table 2). However, it also inhibited basal glucagon gene transcription by about $75 \%$ (Table 1 ). When the treatment of InR1-G9 cells with insulin was extended from 23 to $46 \mathrm{~h}$, the inhibition by insulin of glucagon gene transcription was no longer observed (Fig. 1b, Table 2). Treatment with insulin for $23 \mathrm{~h}$ reduced glucagon mRNA to $58 \%$ in InR1-G9 cells and to $69 \%$ in primary murine islets, consistent with the previous findings [21]. Glucagon mRNA levels were restored in InR1-G9 cells as well as in islets after a $46 \mathrm{~h}$ treatment with insulin (Fig. 1c,d). This indicates that alpha cells lose their insulin responsiveness upon extended exposure to insulin (insulin-induced insulin resistance of alpha cells).
Insulin-induced alpha cell insulin resistance: PKB action and phosphorylation Insulin has been shown before to inhibit glucagon gene transcription through the PI3K-PKB signalling pathway [13]. As has been reported previously [13], insulin induced the phosphorylation of PKB on Ser473 in InR1-G9 cells within 10 min (Fig. 2a, left). This phosphorylation is required for the activation of PKB [22]. However, after extended pretreatment of InR1-G9 cells with insulin for $23 \mathrm{~h}$, the insulin-induced phosphorylation of PKB was markedly reduced (Fig. 2a, left) without a change in the expression level of PKB (Fig. 2a, right).

In the absence of insulin, the expression of a constitutively active form of PKB, myr-PKB, inhibited glucagon gene transcription (Fig. 2b), whereas the kinase-dead mutant myr-PKB-K179M had no effect (Fig. 2b), as has been shown previously [13]. Insulin $(23 \mathrm{~h})$ inhibited glucagon gene transcription (Fig. 2b) and myrPKB could not further enhance this inhibition (Fig. 2b). Insulin
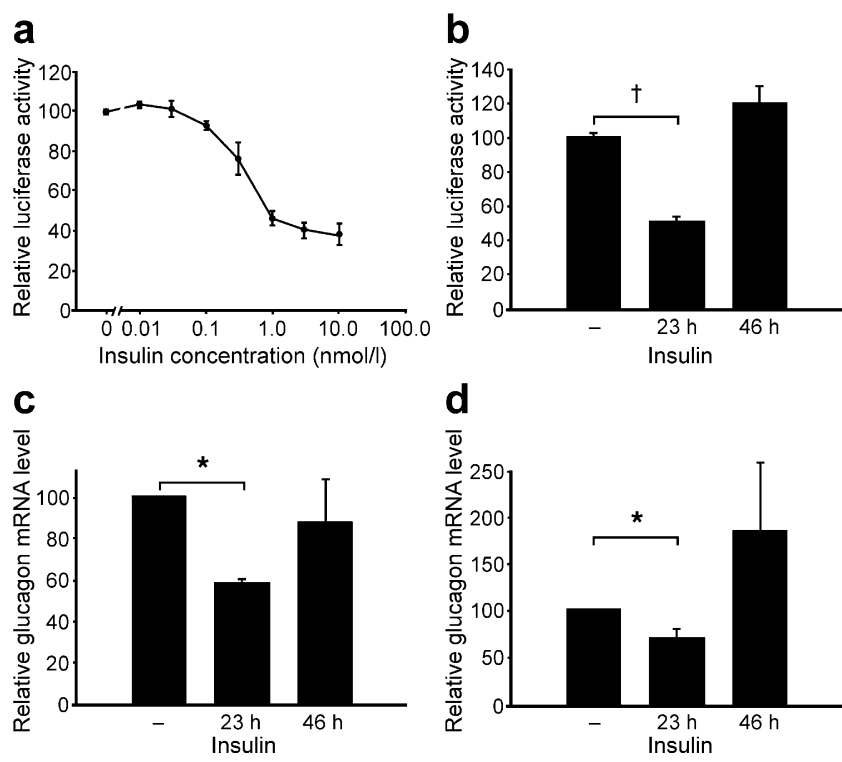

Fig. 1 Loss of insulin-induced inhibition of glucagon gene transcription in a pancreatic islet alpha cell line upon extended exposure of the cells to insulin. InR1-G9 cells were transfected with the plasmid -350 GluLuc. a Concentration-response curve for the inhibition by insulin of glucagon gene transcription. Increasing concentrations of insulin were added $23 \mathrm{~h}$ before harvest. b Loss of insulin-induced inhibition of glucagon gene transcription upon prolonged treatment of the cells with insulin. Insulin $(100 \mathrm{nmol} / \mathrm{l})$ was added 23 or $46 \mathrm{~h}$ before harvest. The luciferase activities are expressed as percentage of the mean value of the activity measured in the untreated controls. Values are means \pm SEM of three independent experiments, each done in duplicate (a), or four independent experiments, each done in triplicate (b). ${ }^{\dagger} p<0.00005$ (one-way ANOVA followed by Scheffé test). c InR1-G9 cells were treated for 23 and $46 \mathrm{~h}$ with insulin $(100 \mathrm{nmol} / \mathrm{l})$ before harvest or were left untreated. d Murine primary islets were isolated and incubated in $5 \mathrm{mmol} / \mathrm{l}$ glucose. Islets were treated with insulin $(100 \mathrm{nmol} / \mathrm{l}) 23$ and $46 \mathrm{~h}$ before harvest or were left untreated. RNA was extracted, cDNA was transcribed and the glucagon mRNA levels were quantified. Values are means \pm SEM of four different experiments. ${ }^{*} p<0.05$ (Student's $t$ test) 
Table 1 Effect of different treatments on basal glucagon gene transcription in InR1-G9 cells

\begin{tabular}{|c|c|c|c|}
\hline Treatment & $\begin{array}{l}\text { Time } \\
\text { (h) }\end{array}$ & $\begin{array}{l}\text { Number } \\
(n)\end{array}$ & $\begin{array}{l}\text { Effect } \\
(\% \text { control })\end{array}$ \\
\hline None & - & 10 & $100 \pm 5$ \\
\hline $10 \mathrm{nmol} / 1$ insulin & 23 & 10 & $52 \pm 9 * * *$ \\
\hline $10 \mathrm{ng} / \mathrm{ml} \mathrm{TNF}-\alpha$ & 24 & 8 & $93 \pm 7$ \\
\hline $10 \mathrm{ng} / \mathrm{ml} \mathrm{TNF}-\alpha$ & 46 & 6 & $94 \pm 6$ \\
\hline $100 \mathrm{ng} / \mathrm{ml} \mathrm{TNF}-\alpha$ & 24 & 4 & $77 \pm 4 * * *$ \\
\hline $20 \mathrm{ng} / \mathrm{ml} \mathrm{IL-6}$ & 24 & 6 & $121 \pm 8$ \\
\hline $20 \mathrm{ng} / \mathrm{ml} \mathrm{IL-6}$ & 46 & 6 & $105 \pm 4$ \\
\hline $10 \mathrm{ng} / \mathrm{ml} \mathrm{IL-1 \beta}$ & 24 & 6 & $25 \pm 1 * * *$ \\
\hline $1 \mathrm{mmol} / 1$ 8-Br-cAMP & 24 & 8 & $190 \pm 26^{* *}$ \\
\hline $1 \mathrm{mmol} / 1$ 8-Br-cAMP & 46 & 6 & $261 \pm 40 * *$ \\
\hline $1 \mu \mathrm{mol} / 1$ dexamethasone & 24 & 6 & $78 \pm 8^{*}$ \\
\hline $1 \mu \mathrm{mol} / 1$ dexamethasone & 46 & 8 & $114 \pm 12$ \\
\hline $300 \mathrm{nmol} / \mathrm{l}$ ciclosporin $\mathrm{A}$ & 24 & 6 & $80 \pm 5 * *$ \\
\hline $300 \mathrm{nmol} / 1$ ciclosporin A & 46 & 4 & $96 \pm 5$ \\
\hline $10 \mathrm{nmol} / 1$ tacrolimus & 24 & 4 & $85 \pm 5$ \\
\hline $10 \mathrm{nmol} / 1$ tacrolimus & 46 & 6 & $82 \pm 4 * *$ \\
\hline $0.2 \mathrm{mmol} / 1 \mathrm{palmitic}$ acid & 24 & 12 & $104 \pm 6$ \\
\hline $0.2 \mathrm{mmol} / 1$ stearic acid & 24 & 14 & $132 \pm 8^{* *}$ \\
\hline $0.4 \mathrm{mmol} / 1$ oleic acid & 24 & 12 & $82 \pm 5 * * *$ \\
\hline $\begin{array}{l}0.2 \mathrm{mmol} / 1 \text { oleic acid }+0.2 \mathrm{mmol} / 1 \\
\text { palmitic acid }\end{array}$ & 24 & 12 & $114 \pm 24$ \\
\hline $0.4 \mathrm{mmol} / 1$ linoleic acid & 24 & 10 & $65 \pm 7 * * *$ \\
\hline $0.4 \mathrm{mmol} / 1$ linolenic acid & 24 & 10 & $46 \pm 4 * * *$ \\
\hline $10 \mu \mathrm{mol} / 1 \mathrm{H}_{2} \mathrm{O}_{2}$ & 24 & 15 & $83 \pm 2 * * *$ \\
\hline $30 \mu \mathrm{mol} / 1 \mathrm{H}_{2} \mathrm{O}_{2}$ & 24 & 15 & $71 \pm 2 * * *$ \\
\hline TRB3 & - & 12 & $277 \pm 17 * * *$ \\
\hline
\end{tabular}

Values are means \pm SEM of the number of experiments indicated $(n)$ InR1-G9 cells were transfected with -350 GluLuc. Treatments started at the time indicated before harvest. TRB3, an expression vector encoding TRB3 was cotransfected $(2 \mu \mathrm{g} / \mathrm{dish})$. The luciferase activities are expressed as percentage of the mean value in each experiment of the activity measured in the untreated controls ${ }^{*} p<0.05,{ }^{*} p<0.01,{ }^{* * *} p<0.001$ (Student's $t$ test)

treatment for $46 \mathrm{~h}$ no longer inhibited glucagon gene transcription. Under this chronic insulin treatment, myrPKB was still able to inhibit glucagon gene transcription, while myr-PKB-K179M did not cause any inhibition (Fig. 2b).

\section{Effect of insulin desensitisation by chronic insulin treatment} on IRS-1 phosphorylation, IR autophosphorylation and IR content in alpha cells As demonstrated by a phosphotyrosine-specific immunoblot (antiphospho-Tyr612-IRS-1), insulin stimulated IRS-1 phosphorylation within $10 \mathrm{~min}$ (Fig. 3). However, after extended pretreatment of InR1-G9 cells with insulin for $23 \mathrm{~h}$, the insulin-induced phosphorylation of IRS-1 was reduced by $86 \%$ (Fig. 3). The extended treatment with insulin ( $23 \mathrm{~h} 10 \mathrm{~min}$ ) did not change the level of IRS-1 (not shown).

Phosphotyrosine-specific immunoblotting (antiphosphoTyr1150/1151-IR) revealed that the insulin-induced autophosphorylation of the IR was virtually abolished after extended pretreatment of InR1-G9 cells with insulin for $23 \mathrm{~h}$ (Fig. 4, left). At the same time, insulin pretreatment for $23 \mathrm{~h}$ reduced the content of the IR by about $90 \%$ (Fig. 4, right). Similarly to the effect of $100 \mathrm{nmol} / 1$ insulin (Fig. 4), the treatment of InR1-G9 cells for $23 \mathrm{~h} 10 \mathrm{~min}$ with $1 \mathrm{nmol} / 1$ insulin decreased the content of the IR by about $80 \%$ (not shown).

The time-course of these effects is shown in Fig. 5a. Insulin treatment of InR1-G9 cells decreased IR autophosphorylation and IR content by about $50 \%$ within $4 \mathrm{~h}$ and by more than $90 \%$ within $8 \mathrm{~h}$ (Fig. 5a). The insulin-induced IR downregulation was completely reversible (Fig. 5b). When insulin was withdrawn after $24 \mathrm{~h}$ of treatment, IR content

Table 2 Effect of different treatments on the insulin-induced inhibition of glucagon gene transcription in InR1-G9 cells

\begin{tabular}{|c|c|c|c|}
\hline Treatment & $\begin{array}{l}\text { Time } \\
\text { (h) }\end{array}$ & $\begin{array}{l}\text { Number } \\
(n)\end{array}$ & $\begin{array}{l}\text { Insulin } \\
E_{\max }\end{array}$ \\
\hline None & 23 & 10 & 100 \\
\hline $10 \mathrm{ng} / \mathrm{ml} \mathrm{TNF}-\alpha$ & 24 & 8 & 113 \\
\hline $10 \mathrm{ng} / \mathrm{ml} \mathrm{TNF}-\alpha$ & 46 & 6 & 107 \\
\hline $100 \mathrm{ng} / \mathrm{ml} \mathrm{TNF}-\alpha$ & 24 & 4 & 117 \\
\hline $20 \mathrm{ng} / \mathrm{ml} \mathrm{IL-6}$ & 24 & 6 & 103 \\
\hline $20 \mathrm{ng} / \mathrm{ml} \mathrm{IL-6}$ & 46 & 6 & 101 \\
\hline $10 \mathrm{ng} / \mathrm{ml} \mathrm{IL}-1 \beta$ & 24 & 6 & $27^{\mathrm{a}}$ \\
\hline $1 \mathrm{mmol} / 1$ 8-Br-cAMP & 24 & 8 & 68 \\
\hline $1 \mathrm{mmol} / 1$ 8-Br-cAMP & 44 & 6 & 82 \\
\hline $1 \mu \mathrm{mol} / 1$ dexamethasone & 24 & 6 & 95 \\
\hline $1 \mu \mathrm{mol} / 1$ dexamethasone & 46 & 8 & 112 \\
\hline $300 \mathrm{nmol} / 1$ ciclosporin $\mathrm{A}$ & 24 & 6 & 76 \\
\hline $300 \mathrm{nmol} / 1$ ciclosporin A & 46 & 4 & 124 \\
\hline $10 \mathrm{nmol} / 1$ tacrolimus & 24 & 4 & 87 \\
\hline $10 \mathrm{nmol} / 1$ tacrolimus & 46 & 6 & 97 \\
\hline $0.2 \mathrm{mmol} / 1 \mathrm{palmitic}$ acid & 24 & 6 & 105 \\
\hline $0.2 \mathrm{mmol} / 1$ stearic acid & 24 & 6 & 104 \\
\hline $0.4 \mathrm{mmol} / 1$ oleic acid & 24 & 8 & 113 \\
\hline $\begin{array}{l}0.2 \mathrm{mmol} / 1 \text { oleic acid }+0.2 \mathrm{mmol} / 1 \\
\text { palmitic acid }\end{array}$ & 24 & 6 & 143 \\
\hline $0.4 \mathrm{mmol} / 1$ linoleic acid & 24 & 4 & 76 \\
\hline $0.4 \mathrm{mmol} / 1$ linolenic acid & 24 & 4 & 115 \\
\hline $10 \mu \mathrm{mol} / 1 \mathrm{H}_{2} \mathrm{O}_{2}$ & 24 & 15 & 100 \\
\hline $3 \mu \mathrm{mol} / 1 \mathrm{H}_{2} \mathrm{O}_{2}$ & 24 & 15 & 102 \\
\hline TRB3 & - & 12 & 111 \\
\hline $100 \mathrm{nmol} / 1$ insulin (chronic insulin) & 46 & 8 & $0^{\mathrm{a}}$ \\
\hline
\end{tabular}

Values are shown as the mean of the number of experiments indicated $(n)$ InR1-G9 cells were transfected with -350 GluLuc, and insulin was added in increasing concentrations $23 \mathrm{~h}$ before harvest. The treatments started to the time indicated before harvest. TRB3, an expression vector encoding TRB3 was cotransfected ( $2 \mu \mathrm{g}$ per dish). The insulin concentration-response curve under treatment was compared with an insulin concentration-response curve without treatment run in parallel in each experiment. An example of a concentration-response curve is shown in Fig. 1a. The maximal inhibition by insulin under treatment (Insulin $E_{\max }$ ) is expressed as percentage of the maximal inhibition by insulin without treatment

${ }^{\mathrm{a}}$ Indicates the two treatments that virtually abolished the insulininduced inhibition of glucagon gene transcription. No changes in the $\mathrm{IC}_{50}$ value of insulin were observed for any treatment (not shown) 


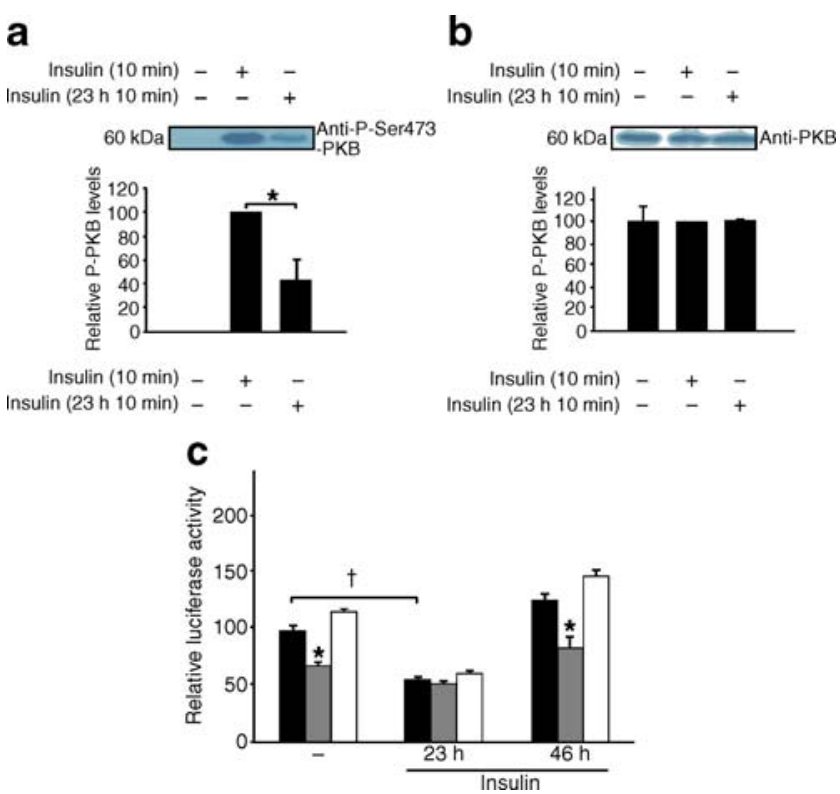

Fig. 2 Effect of chronic insulin treatment on the insulin-induced PKB phosphorylation and PKB-induced inhibition of glucagon gene transcription in pancreatic islet alpha cells. a, b PKB phosphorylation and level. InR1-G9 cells were treated with insulin $(100 \mathrm{nmol} / \mathrm{l})$ for $10 \mathrm{~min}$ or $23 \mathrm{~h} 10 \mathrm{~min}$ or left untreated. Cell lysates were subjected to immunoblotting with antiphospho-Ser473-PKB (Anti-P-Ser473-PKB; a) or anti-PKB antibodies (b). Representative immunoblots are shown in the upper panels. Lower panels, densitometry; values are normalised to the $10 \mathrm{~min}$ insulin group (a) or untreated group (b). Values are means \pm SEM of four independent experiments. P-PKB, phospho-Ser473-PKB. ${ }^{*} p<0.05$ (Student's $t$ test). c PKB-induced inhibition of glucagon gene transcription. InR1-G9 cells were transfected with -350 GluLuc (black bars) together with plasmids encoding myr-PKB (hatched bars) or myr-PKB-K179M (white bars), as indicated. Insulin $(100 \mathrm{nmol} / \mathrm{l})$ was added 23 or $46 \mathrm{~h}$ before harvest. The luciferase activities are expressed as percentage of the mean value of the activity measured in the controls (no insulin, no myr-PKB, no myr-PKB-K179M). Values are means \pm SEM of three independent experiments, each performed in triplicate. ${ }^{*} p<0.05,{ }^{\dagger} p<0.00005$ (oneway ANOVA followed by Scheffé test)

recovered to about $50 \%$ of controls within 9 and $5 \mathrm{~h}$ in the presence or absence of serum, respectively (Fig. $5 b$ ).

\section{Effect of insulin desensitisation by chronic insulin treatment} on IR synthesis and degradation The labelling of the IR with $\left[{ }^{35} \mathrm{~S}\right]$ methionine was not changed by the treatment of InR1-G9 cells with insulin for $24 \mathrm{~h}$ (data not shown), suggesting that chronic $(24 \mathrm{~h})$ insulin treatment does not inhibit IR synthesis.

In the presence of the protein synthesis inhibitor cycloheximide, insulin enhanced the decrease in IR levels (Fig. 6), suggesting that insulin stimulates the degradation of the IR.

Further experiments were performed to characterise the degradation pathways involved. The inhibitor of proteasomal degradation, lactacystin [23], did not prevent the

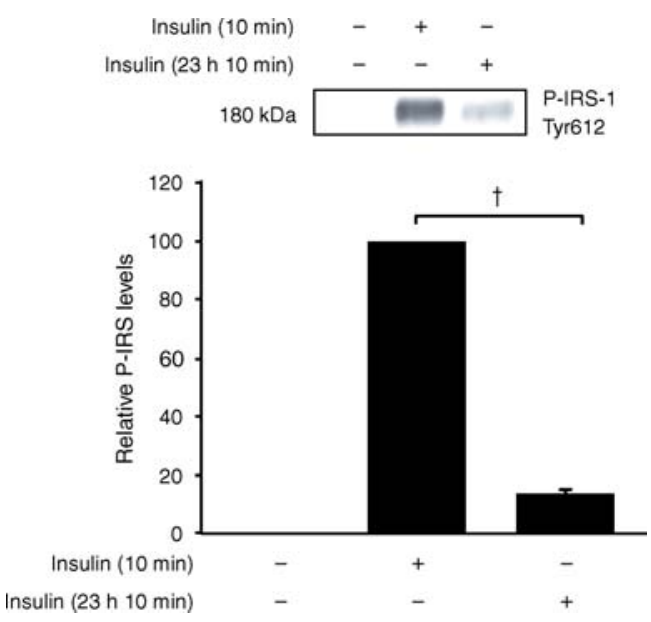

Fig. 3 Effect of chronic insulin treatment on the insulin-induced IRS1 phosphorylation in pancreatic islet alpha cells. InR1-G9 cells were treated with insulin $(100 \mathrm{nmol} / \mathrm{l})$ for $10 \mathrm{~min}$ or $23 \mathrm{~h} 10 \mathrm{~min}$ or left untreated. Cell lysates were subjected to immunoblotting with antiphospho-Tyr612-IRS-1 (P-IRS-1 Tyr612) antibodies. A representative immunoblot is shown in the upper panel. Lower panel, densitometry; values are normalised to the $10 \mathrm{~min}$ insulin group. Values are means \pm SEM of three independent experiments. ${ }^{\dagger} p<$ 0.00001 (Student's $t$ test). P-IRS, phosphorylated IRS

insulin-induced downregulation of the IR (Fig. 7a). However, lactacystin effectively prevented the degradation of $\beta$ catenin, induced by the thiazolidindione rosiglitazone bound to the peroxisome-proliferator activated receptor $\gamma$ (Electronic supplementary material [ESM] Fig. 1) [24]. $\beta$ Arrestins were found to be heavily produced in InR1-G9 cells (Fig. 7b) and have been suggested to interact with the IR [25]. However, insulin did not induce a cytosol-tomembrane translocation of $\beta$-arrestins in InR1-G9 cells

a

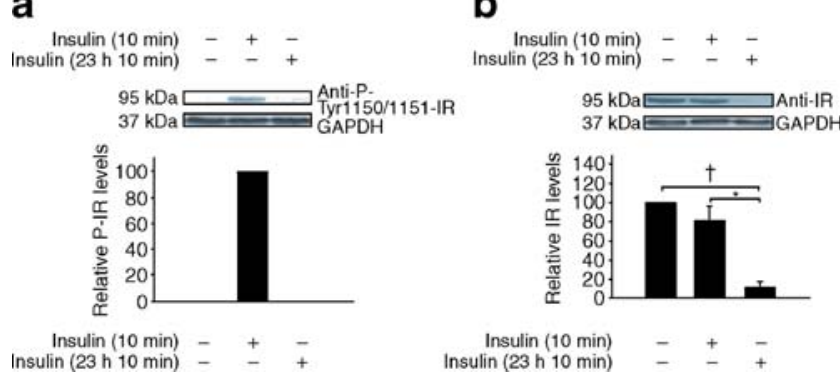

Fig. 4 Effect of chronic insulin treatment on insulin-induced IR autophosphorylation and IR levels in pancreatic islet alpha cells. InR1-G9 cells were treated with insulin $(100 \mathrm{nmol} / \mathrm{l})$ for $10 \mathrm{~min}$ or $23 \mathrm{~h} 10 \mathrm{~min}$ or left untreated. Cell lysates were subjected to immunoblotting with antiphospho-Tyr1150/Tyr1151-IR (Anti-PTyr1150/1151-IR; a) or anti-IR- $\beta$ (Anti-IR; b) antibodies. Representative immunoblots are shown in the upper panels. Lower panels, densitometry; values are normalised to the $10 \mathrm{~min}$ insulin group (left) or untreated group (right). Values are means \pm SEM of three independent experiments. ${ }^{*} p<0.05,{ }^{\dagger} p<0.00001$ (Student's $t$ test). PIR, phosphorylated IR 
a

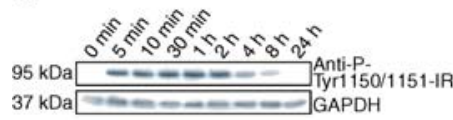

b

$37 \mathrm{kDa}$ GAPDH

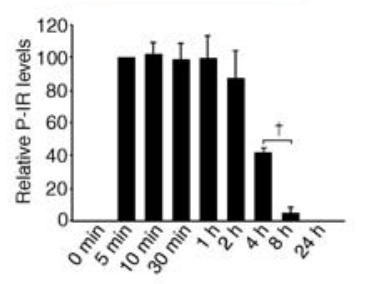

C

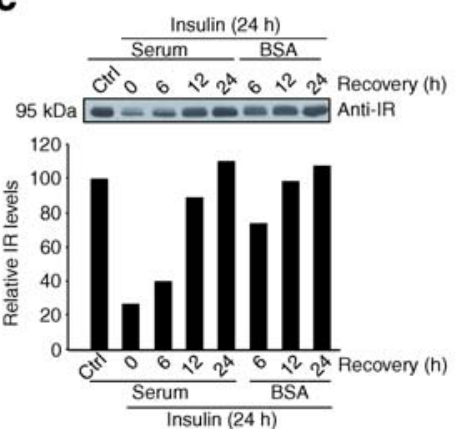

Fig. 5 Time-course of the effect of chronic insulin treatment on insulin-induced IR autophosphorylation and IR levels and its reversibility in pancreatic islet alpha cells. a, b Time-course. InR1G9 cells were treated with insulin $(100 \mathrm{nmol} / \mathrm{l})$ for the time indicated or left untreated. Cell lysates were subjected to immunoblotting with antiphospho-Tyr1150/Tyr1151-IR (Anti-P-Tyr1150/1151-IR; a) or anti-IR- $\beta$ (Anti-IR, b) antibodies. Representative immunoblots are shown in the upper panels. Lower panels, densitometry, values are normalised to the $5 \mathrm{~min}$ insulin group (a) or untreated group (b). Values are means $\pm \mathrm{SEM}$ of four independent experiments. ${ }^{*} p<0.05$, ${ }^{\dagger} p<0.005$ (paired Student's $t$ test). c Reversibility. InR1-G9 cells were treated with insulin $(100 \mathrm{nmol} / \mathrm{l})$ for $24 \mathrm{~h}$ or left untreated (Ctrl). Insulin was then withdrawn and the cells were incubated without adding insulin for the time indicated (Recovery) in the presence (Serum) or absence of serum (BSA, which replaced serum proteins). Cell lysates were subjected to immunoblotting with anti-IR- $\beta$ (AntiIR) antibodies. Upper panel, immunoblot. Lower panel, densitometry. A representative experiment of three independent experiments is shown

(Fig. 7b), although, serving as positive control, chemokine (C-C motif) ligand 5 (CCL5) stimulated membrane translocation of $\beta$-arrestins in rat basophilic leukaemia cells stably expressing the human chemokine receptor 5 , as has been shown before [17]. The lack of insulin-induced membrane translocation provides no evidence for an interaction between the liganded IR and $\beta$-arrestins in glucagon-producing alpha cells. The lysosomotropic agent chloroquine [26-28] reduced insulin-induced IR downregulation, as in the presence of chloroquine the treatment of InR1-G9 cells with insulin for $8 \mathrm{~h}$ did not produce a significant decrease of IR levels (Fig. 7c). Longer treatment periods could not be studied because $25 \mathrm{~h}$ chloroquine treatment exerted detrimental effects on the viability of InR1-G9 cells (Fig. 7c and data not shown).

\section{Discussion}

The IR is a transmembrane receptor that belongs to the tyrosine kinase family of receptors. Insulin binding induces receptor autophosphorylation followed by IRS recruitment and phosphorylation at multiple tyrosine residues, which then serve as starting points for diverse signalling pathways, including the PI3K-PKB signalling pathway to the glucagon gene in pancreatic islet alpha cells $[12,13]$. The responsiveness of a target organ to insulin is subject to regulation. This phenomenon is best demonstrated by the well-known presence of insulin resistance of skeletal muscle, adipose tissue and the liver in diabetes mellitus type 2 [1]. In this disease, insulin resistance is evidently present also at the pancreatic islet alpha cells, as is indicated by hyperglucagonaemia in the face of hyperinsulinaemia [4-11]. Diabetes mellitus type 2 is thus indeed a bihormonal disease with relative insulin deficiency and glucagon excess, as already stated by R. H. Unger and L. Orci more than 30 years ago [8]. However, to date there is no information about the agents that induce insulin resistance at the level of the pancreatic islet alpha cells. The results of the present study now suggest that hyperinsulinaemia with subsequent IR downregulation
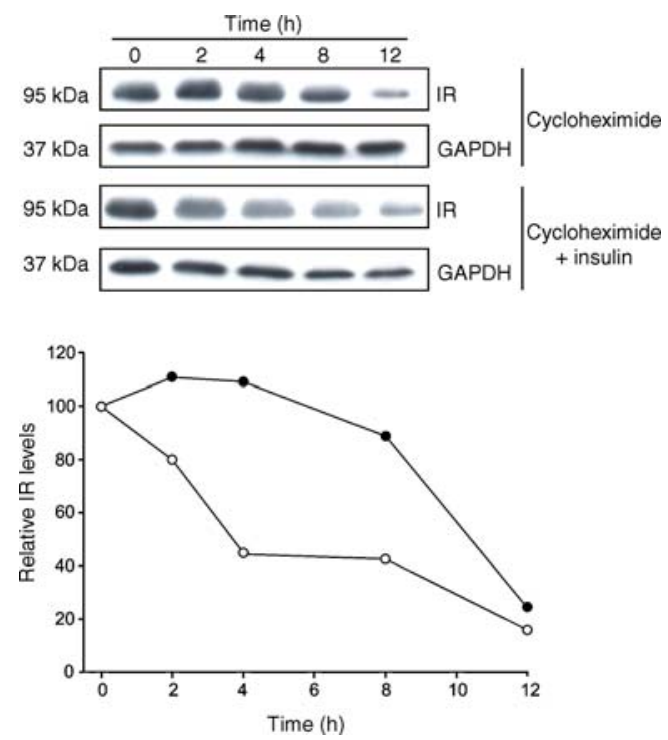

Fig. 6 Effect of insulin on IR levels in the presence of the protein synthesis inhibitor cycloheximide in pancreatic islet alpha cells. Cycloheximide alone $(50 \mu \mathrm{g} / \mathrm{ml})$ (black circles) or cycloheximide $(50 \mu \mathrm{g} / \mathrm{ml})$ plus insulin $(100 \mathrm{nmol} / \mathrm{l})$ (white circles) was added to InR1-G9 cells, and the cells were then incubated for the time indicated. Cell lysates were subjected to immunoblotting with antiIR- $\beta$ antibody. Upper panel, immunoblot. Lower panel, densitometry, normalised to the untreated group 
a

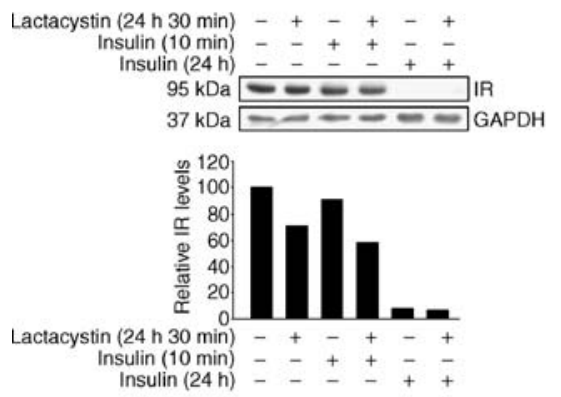

b

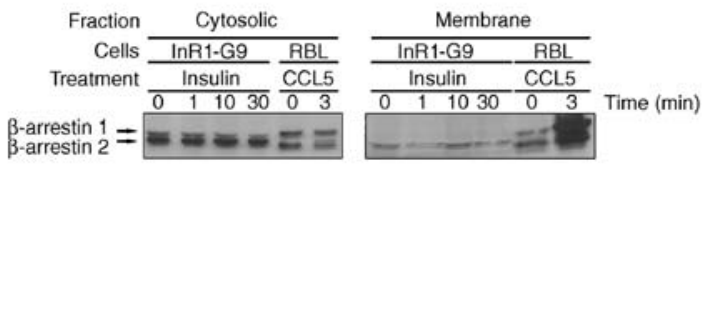

c

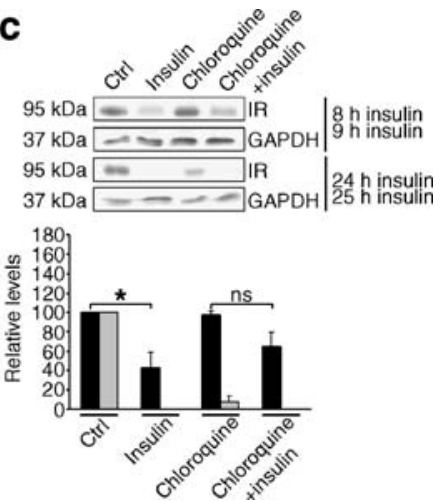

Fig. 7 Examination of potential IR degradation pathways in pancreatic islet alpha cells. a Effect of the proteasome inhibitor lactacystin on insulin-induced IR downregulation. InR1-G9 cells were incubated with insulin $(100 \mathrm{nmol} / \mathrm{l}$; for $10 \mathrm{~min}$ or $24 \mathrm{~h})$ in the presence or absence of lactacystin $(5 \mu \mathrm{mol} / 1$; added $24 \mathrm{~h} 30 \mathrm{~min}$ before harvest). Cell lysates were subjected to immunoblotting with anti-IR- $\beta$ antibody. Upper panel, immunoblot. Lower panel, densitometry, normalised to the untreated group. b Effect of insulin on $\beta$-arrestin levels in cytosolic and membrane fractions of InR1-G9 cells. InR1-G9 cells were treated with insulin $(100 \mathrm{nmol} / \mathrm{l})$ for the time indicated. Cytosolic and membrane fractions were subjected to immunoblotting with anti- $\beta$-arrestin antibodies. The CCL5-induced membrane trans-

may be one of the mechanisms that confer insulin resistance to glucagon-producing pancreatic islet alpha cells.

From among the 16 agents that are considered to be involved in the development of insulin resistance in some other tissues [1], and which were tested in the present study, 14 did not relieve alpha cells of the insulin-induced inhibition of glucagon gene transcription under the experimental conditions used. Nevertheless, TNF- $\alpha$, non-saturated fatty acids and hydrogen peroxide inhibited glucagon gene transcription by themselves, which has not been reported before. The mechanisms and significance of these effects remain to be studied. The inhibition by TNF- $\alpha$, for example, could play a role in sepsis-induced hypoglycaemia [29].

The mammalian homologue TRB3 has been reported to block PKB activation by insulin in the liver [2]. It stimulated glucagon gene transcription, which is consistent with PKB inhibition, if basal glucagon gene transcription is restricted by PKB. If so, TRB3 appears not to reach critical cellular compartments, since it did not prevent the insulininduced inhibition of glucagon gene transcription, although this effect is mediated by PKB activation [13].

One of the two messenger molecules that were tested in the present study, and which abolished the insulin-induced inhibition of glucagon gene transcription, was IL-1 $\beta$. This effect of IL- $1 \beta$ is, however, difficult to interpret, since IL-1 $\beta$ markedly decreased basal glucagon gene transcription by itself. This decrease also questions a role for IL- $1 \beta$ in the development of alpha cell insulin resistance, because it contrasts with elevated glucagon levels in diabetes mellitus type 2. location of $\beta$-arrestins in rat basophilic leukaemia cells (RBL) served as positive control [16]. $\mathbf{c}$ Effect of the lysosomal degradation inhibitor chloroquine on insulin-induced IR downregulation. InR1-G9 cells were treated with insulin $(100 \mathrm{nmol} / \mathrm{l}$, for 8 or $24 \mathrm{~h}$ as indicated) in the presence or absence of chloroquine $(200 \mu \mathrm{mol} / \mathrm{l}$, added at 9 or $25 \mathrm{~h}$, respectively, before harvest). Cell lysates were subjected to immunoblotting with anti-IR- $\beta$ antibody. Upper panel, representative immunoblot. Lower panel, densitometry; values are normalised to the untreated group (Ctrl). Black bars, $8 \mathrm{~h}$ insulin; grey bars, $24 \mathrm{~h}$ insulin. Values are means \pm SEM of three independent experiments. ${ }^{*} p<0.05$; n.s., not significant (Student's $t$ test)

The other agent that was found in the present study to abolish the insulin-induced inhibition of glucagon gene transcription was insulin itself: a prolonged action of insulin on alpha cells led to a loss of the insulin response. Factors such as secinH3, TNF- $\alpha$ and fatty acids have been shown to interfere with insulin signalling at a level downstream of the IR when conferring insulin resistance to some other tissues $[1,30]$. In the insulin-desensitised alpha cell line, the overproduction of PKB still inhibited glucagon gene transcription and the insulin-induced phosphorylation, and thus activation of PKB was markedly reduced, all indicating that the insulin-induced defect in insulin signalling is upstream of PKB. The location of the alteration responsible for the insulin-resistant state of alpha cells may reside in the IR, since chronic insulin markedly reduced IRS-1 phosphorylation, IR autophosphorylation and IR levels. IR downregulation was a time-dependent and reversible process. The insulin-induced decrease in IR autophosphorylation was synchronous with and appears thus to be secondary to the decrease in IR levels. The IR levels were decreased by insulin to about $50 \%$ within $4 \mathrm{~h}$ and by more than $90 \%$ within $8 \mathrm{~h}$. This time-course suggests that the concentration-response curve shown in Fig. 1 may underestimate the inhibition by insulin of glucagon gene transcription, because of rapid desensitisation. Chronic insulin treatment did not change the labelling of the IR with $\left[{ }^{35} \mathrm{~S}\right]$ methionine but did enhance its elimination in the presence of the protein synthesis inhibitor cycloheximide, indicating that IR downregulation was due to enhanced degradation of the IR. $\beta$-Arrestins are best known for complex formation with 
seven-transmembrane receptors following agonist binding and receptor phosphorylation by G-protein-coupled receptor kinases [14]. Binding of $\beta$-arrestin to the cytoplasmic domain of seven-transmembrane receptors interrupts heterotrimeric G-protein interaction with the receptor [17]. Recently, $\beta$-arrestins have been implicated also in the ubiquitination and downregulation of the insulin-like growth factor-1 receptor [31]. They are also able to associate with the liganded IR [23] and may interfere with insulin signalling [32]. However, insulin did not induce a cytosol-to-membrane translocation of $\beta$-arrestins in alpha cells, providing no evidence for an interaction of the IR with $\beta$-arrestins. Furthermore, the inhibitor of proteasomal degradation, lactacystin [23], did not prevent IR downregulation, whereas the lysosomotropic agent chloroquine [26-28] reduced it to some degree. When taken together, these results demonstrate that a prolonged treatment of alpha cells with insulin abolishes insulin-induced inhibition of glucagon gene transcription; this desensitisation of alpha cells is associated with and may be secondary to IR downregulation, which follows from enhanced IR degradation that may involve lysosomal pathways.

The novel finding of the present study is that insulin is able to induce insulin resistance in pancreatic islet alpha cells, as it does in skeletal muscle, fat and liver cells [1, 3237]. This finding may be of particular importance for the understanding of diabetes mellitus type 2. Hyperinsulinaemia is a hallmark of diabetes mellitus type 2 and an early event in the development of the disease. At early stages, insulin resistance is overcome by an increase in insulin secretion; this secondary hyperinsulinaemia together with other metabolic derangements might contribute in a feedforward manner to progressive insulin resistance [1]. On the other hand, hyperinsulinaemia can be the primary event. Transgenic mice overproducing a dominant negative mutant of carcinoembryonic antigen-related cell adhesion molecule 1 (CEACAM1), which, as wild-type, promotes insulin degradation in the liver, developed hyperinsulinaemia resulting from impaired insulin clearance; the hyperinsulinaemia caused secondary insulin resistance [38]. Noteworthy, this insulin resistance was associated with a decrease by $50 \%$ of the IR number in hepatocytes [38], which is reminiscent of IR downregulation associated with insulin resistance in pancreatic islet alpha cells, as observed in the present study. Insulin-induced desensitisation may be particularly relevant for alpha cells, which are located next to insulin-producing beta cells within the pancreatic islets [39] and are thus exposed to high insulin levels. Loss of the pulsatile pattern of insulin secretion, as has been suggested to occur in diabetes mellitus type 2 [40-42], leads to a steady exposure of alpha cells to insulin, further promoting insulin desensitisation. By providing direct evidence for self-modulation by insulin of the insulin sensitivity in a pancreatic islet alpha cell line, the present study suggests that insulin-induced insulin resistance of pancreatic islet alpha cells underlies the relative glucagon excess in diabetes mellitus type 2 .

Acknowledgements The TRB3 expression vector was generously provided by S. Herzig, Heidelberg, Germany. We thank M. Oppermann and F. Hüttenrauch, Göttingen, Germany, for their guidance in the $\beta$-arrestin experiments. The support of M. González by the Deutscher Akademischer Austauschdienst and the Consejo Nacional de Ciencia y Tecnologia (DAAD, CONACyT) is gratefully acknowledged. This work was supported by the Deutsche Forschungsgemeinschaft (SFB402/A3 and GRK335).

Duality of interest The authors declare that there is no duality of interest associated with this manuscript.

Open Access This article is distributed under the terms of the Creative Commons Attribution Noncommercial License which permits any noncommercial use, distribution, and reproduction in any medium, provided the original author(s) and source are credited.

\section{References}

1. Kahn SE, Hull RL, Utzschneider KM (2006) Mechanisms linking obesity to insulin resistance and type 2 diabetes. Nature 444:840846

2. Du K, Herzig S, Kulkarni RN, Montminy M (2003) TRB3: a tribbles homolog that inhibits Akt/PKB activation by insulin in liver. Science 300:1574-1577

3. Oetjen E, Baun D, Beimesche B et al (2003) Inhibition of human insulin gene transcription by the immunosuppressive drugs cyclosporin A and tacrolimus in primary, mature islets of transgenic mice. Mol Pharmacol 63:1289-1295

4. Reaven GM, Chen YD, Golay A, Swislocki AL, Jaspan JB (1987) Documentation of hyperglucagonemia throughout the day in nonobese and obese patients with noninsulin-dependent diabetes mellitus. J Clin Endocrinol Metab 64:106-110

5. Baron AD, Schaeffer L, Shragg P, Koltermann OG (1987) Role of hyperglucagonemia in maintenance of increased rates of hepatic glucose output in type II diabetics. Diabetes 36:274-283

6. Brand CL, Jorgensen PN, Svendson I, Holst JJ (1996) Evidence for a major role of glucagon in regulation of plasma glucose in conscious, nondiabetic, and alloxan induced diabetic rabbits. Diabetes 45:1076-1083

7. Larsson H, Ahrén B (2000) Glucose intolerance is predicted by low insulin and high glucagon secretion: outcome of a prospective study in postmenopausal Caucasian women. Diabetologia 43:194 202

8. Unger RH, Orci L (1975) The essential role of glucagon in the pathogenesis of diabetes mellitus. Lancet 1:14-16

9. Lefebvre PJ (1995) Glucagon and its family revisited. Diabetes Care 18:715-730

10. Unger RH, Orci L (1981) Glucagon and the A cell: physiology and pathophysiology (first of two parts). N Engl J Med 304:15181524

11. Unger RH, Orci L (1981) Glucagon and the A cell: physiology and pathophysiology (second of two parts). N Engl J Med 304:1575-1580

12. Grzeskowiak R, Amin J, Oetjen E, Knepel W (2000) Insulin responsiveness of the glucagon gene promoter is conferred by interactions between proximal promoter and more distal enhancer- 
like elements involving the paired-domain transcription factor Pax6. J Biol Chem 275:30037-30045

13. Schinner S, Barthel A, Dellas C et al (2005) Protein kinase B activity is sufficient to mimic the effect of insulin on glucagon gene transcription. J Biol Chem 280:7369-7376

14. Bünemann M, Hosey MM (1999) G-protein coupled receptor kinases as modulators of G-protein signalling. J Physiol 517:5-23

15. Salehi A, Vieira E, Gylfe E (2006) Paradoxical stimulation of glucagon secretion by high glucose concentrations. Diabetes 55:2318-2323

16. Schwaninger M, Blume R, Oetjen E, Lux G, Knepel W (1993) Inhibition of cAMP responsive element-mediated gene transcription by cyclosporin A and FK506 after membrane depolarization. J Biol Chem 268:23111-23115

17. Hüttenrauch F, Pollok-Kopp B, Oppermann M (2005) G proteincoupled receptor kinases promote phosphorylation and betaarrestin-mediated internalization of CCR5 homo- and heterooligomers. J Biol Chem 280:37503-37515

18. Kisanuki K, Kishikawa H, Araki E et al (1995) Expression of insulin receptor on clonal pancreatic alpha cells and its possible role for insulin-stimulated negative regulation of glucagon secretion. Diabetologia 38:422-429

19. Krätzner R, Fröhlich F, Lepler K et al (2008) A peroxisome proliferator-activated receptor $\gamma$-retinoid $\mathrm{X}$ receptor heterodimer physically interacts with the transcriptional activator PAX6 to inhibit glucagon gene transcription. Mol Pharmacol 73:509-517

20. Oetjen E, Diedrich T, Eggers A, Eckert B, Knepel W (1994) Distinct properties of the cAMP-responsive element of the rat insulin I gene. J Biol Chem 269:27036-27044

21. Philippe J (1989) Glucagon gene transcription is negatively regulated by insulin in a hamster islet cell line. J Clin Invest 84:672-677

22. Alessi DR, Cohen P (1998) Mechanism of activation and function of protein kinase B. Curr Opin Genet Dev 8:55-62

23. Dick LR, Cruishank AA, Grenie L, Melandri FD, Nunes SL, Stein RL (1996) Mechanistic studies on the inactivation of the proteasome by lactacystin: a central role for clasto-lactacystin beta-lactone. J Biol Chem 271:7273-7276

24. Sharma C, Pradeep A, Wong L, Rana A, Rana B (2004) Peroxisome proliferators activated receptor $\gamma$ activation can regulate $\beta$-catenin levels via a proteasome mediated and adenomatous polyposis coli-independent pathway. J Biol Chem 279:35583-35594

25. Dalle S, Ricketts W, Imamura T, Vollenweider P, Olefsky JM (2001) Insulin and insulin-like growth factor I receptors utilize different $G$ protein signaling components. J Biol Chem 276:15688-15695

26. de Duve C (2005) The lysosome turns fifty. Med Sci (Paris) 21:12-15 (article in French)

27. Marshall S, Olefsky JM (1976) Effects of lysosomotropic agents on insulin interactions with adipocytes. Evidence for a lysosomal pathway for insulin processing and degradation. J Biol Chem 254:10153-10160

28. Wibo M, Poole B (1974) Protein degradation in cultured cells. II. The uptake of chloroquine by rat fibroblasts and the inhibition of cellular protein degradation and cathepsin B1. J Cell Biol 63:430 440

29. Darling G, Goldstein DS, Stull R, Gorschboth CM, Norton JA (1989) Tumor necrosis factor: immune endocrine interaction. Surgery 106:1155-1160

30. Hafner M, Schmitz A, Grüne I et al (2006) Inhibition of cytohesins by SecinH3 leads to hepatic insulin resistance. Nature 444:941-944

31. Girnita L, Shenoy SK, Sehat B et al (2005) $\beta$-arrestin is crucial for ubiquitination and down-regulation of the insulin like growth factor-1 receptor by acting as adaptor for the MDM2 E3 ligase. J Biol Chem 280:24412-24419

32. Usui I, Imamura T, Babendure JL et al (2005) G-protein-coupled receptor kinase 2 mediates endothelin-1-induced insulin resistance via the inhibition of both Galphaq/11 and insulin receptor substrate-1 pathways in 3T3-L1 adipocytes. Mol Endocrinol 19:2760-2768

33. Heaton JH, Gelehrter TD (1981) Desensitization of hepatoma cells to insulin action. Evidence for a post-receptor mechanism. J Biol Chem 256:12257-12262

34. Treadway JL, Whittaker J, Pessin JE (1989) Regulation of the insulin receptor kinase by hyperinsulinism. J Biol Chem 264:1513615143

35. Blackard WG, Guzelian PS, Small ME (1978) Down regulation of insulin receptors in primary cultures of adult rat hepatocytes in monolayer. Endocrinology 103:548-553

36. Livingston JN, Purvis BJ, Lockwood DH (1978) Insulin-dependent regulation of the insulin-sensitivity of adipocytes. Nature 273:394-396

37. Mott DM, Howard BV, Bennett PH (1979) Stoichiometric binding and regulation of insulin receptors on human diploid fibroblasts using physiologic insulin levels. J Biol Chem 254:8762-8767

38. Poy MN, Yang Y, Rezaei K et al (2002) CEACAM1 regulates insulin clearance in liver. Nat Genet 30:270-276

39. Weir GC, Bonner-Weir S (1990) Islets of Langerhans: the puzzle of intraislet interactions and their relevance to diabetes. J Clin Invest 85:983-987

40. Meneilly GS, Veldhuis JD, Elahi D (1999) Disruption of the pulsatile and entropic modes of insulin release during an unvarying glucose stimulus in elderly individuals. J Clin Endocrinol Metab 84:1938-1943

41. Grubert JM, Lautz M, Lacy DB et al (2005) Impact of continuous and pulsatile insulin delivery on net hepatic glucose uptake. Am J Physiol Endocrinol Metab 289:E232-E240

42. Bergsten P, Lin J, Westerlund J (1998) Pulsatile insulin release: role of cytoplasmic $\mathrm{Ca}^{2+}$ oscillations. Diabetes Metab 24:41-45 